\section{EMPLOYMENT OPPORTUNITIES}

\section{INFECTION CONTROL COORDINATOR \\ Portland, Oregon}

Full-time, day position available for $\mathrm{RN}$ or Med Tech to be responsible for the continuing development and implementation of Infection Control Program for Good Samaritan Hospital and Medical Center. Responsibilities will include infection surveillance, and education and consultation regarding infection control practices.

Requires current license, National Certification in Infection Control, a minimum of one year experience in clinical epidemiology, computer familiarity and strong interpersonal/ communication skills.

Please send resume or call Lynette Keck at (503)229-7265 for more information.

\section{GOOD SAMARITAN HOSPITAL AND MEDICAL CENTER 2282 NW NORTHRUP PORTLAND, OREGON 97210 \\ A Member of Legacy Health System Equal Opportunity Employer}

HOSPITAL EPIDEMIOLOGIST/INFECTION CONTROL Cedars-Sinai Medical Center/UCLA School of Medicine is recruiting for a physician, trained in internal medicine/ infectious disease and 3-5 years experience in infection control to develop and implement program on hospitalwide basis. Teaching essential. Academic appointment proposed at appropriate level in academic series. Equal Opportunity Employer. Respond to: Richard D. Meyer, M.D., Division of Infectious Diseases, B-226, Cedars-Sinai Medical Center, 8700 Beverly Boulevard, Los Angeles, CA 90048-0750.

\section{INFECTION CONTROL DIRECTOR}

Our expanding healthcare system in the beachside town of Melbourne, on Florida's East Coast, is seeking an experienced $\mathrm{RN}$ to join us in the capacity of Infection Control Director.

This position will over see activities at both of our technologically advanced facilities-468-bed Holmes Regional Medical Center and the new 60-bed Palm Bay Community Hospital. Key responsibilities will include program assessment and development. We prefer to hire an RN with Infection Control certification, a Master's degree in Public Health or related field, and proven experience in acute care infectious disease management.

In return for your expertise, we'll provide an attractive salary and excellent comprehensive benefits package including employer-matched pension plan You'll also enjoy our beautiful coastal Florida ltxation which offers the advantages of affordable housing and no state income tax.

For immediate, confidential consideration, please phone Iris Spikes, RN, Nurse Recruiter at (407) 676-7239. Or send your resume to Iris at: Holmes Regional Medical Center, 1350 S. Hickory St., Melbourne, FL 32902.We are an equal opportunity employer.

\section{Holmes Regional} Medical Center, Inc.

\section{SHARING THE SCIENCE OF WELLNESS}

\title{
re.sponse \ri-spän(t)s।
}

\section{保}

That's what you want from a classified ad. And Classified Marketplace lets you reach the audience you want-cost effectively-to get you the response you need.

- Employment Opportunities

- Positions Wanted

- Meetings

- Services
- Educational Opportunities

- For Sale/For Rent

- Miscellaneous

- Wanted
RATES

Typesetting Available

Line Advertising - \$22 per line, $\$ 132$ minimum Classified advertising is non-commissionable

\section{Contact our Classified Advertising Representative} for help in placing your customized ad message:

Call toll-free or send typed copy to:

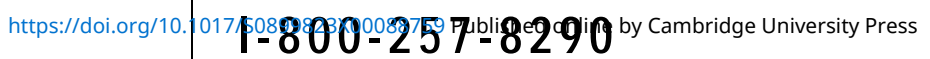

Donna Coles 6900 Grove Road

Thorofare. NJ 08086-9447 


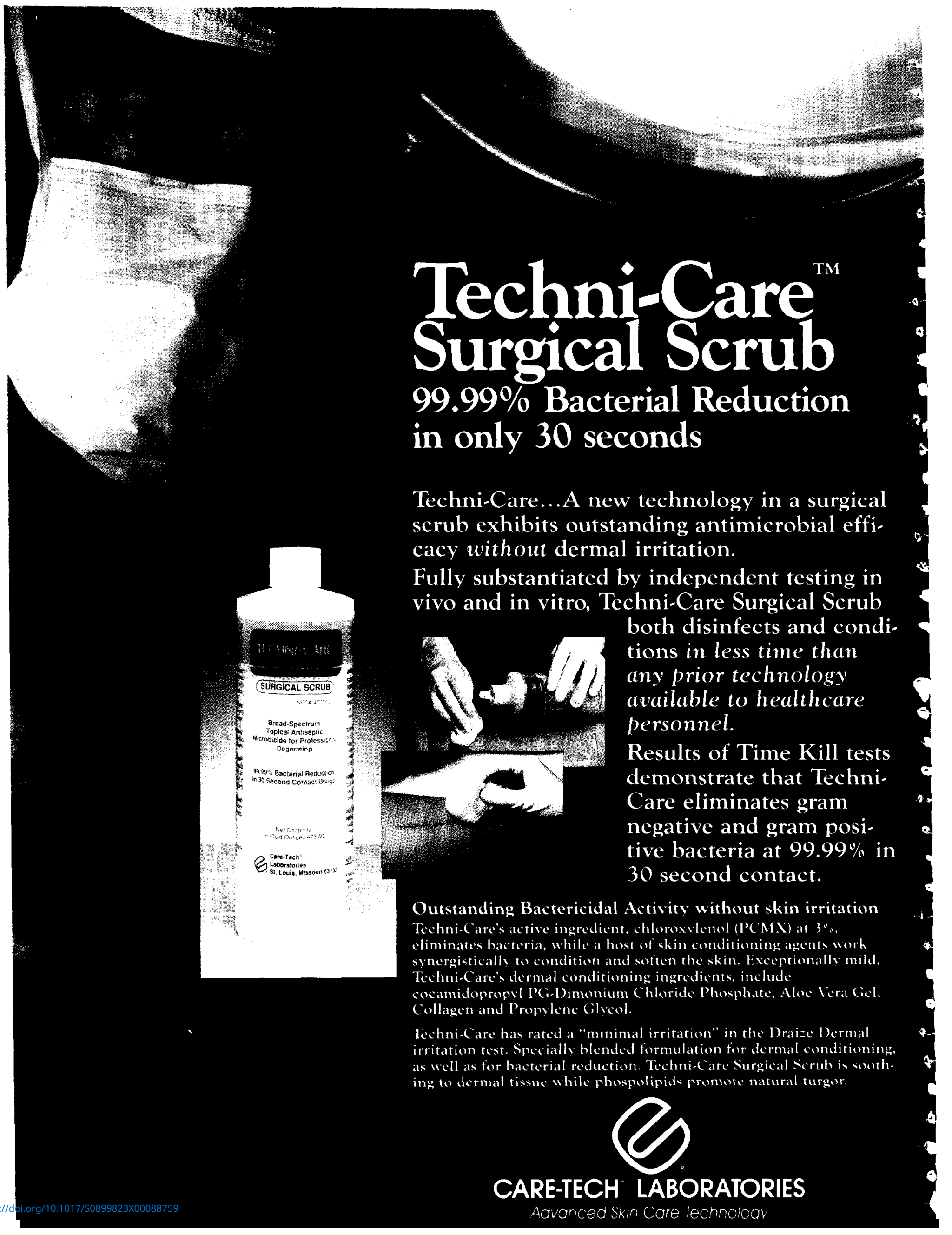

